\title{
Proximate composition analysis posterior to the cryopreservation of Chaetoceros calcitrans
}

\section{Análisis de la composición proximal de Chaetoceros calcitrans posterior a su criopreservación}

\author{
Joan Salas-Leiva, ${ }^{1 *}$ Ph.D, Enrique Dupré M, ${ }^{1}$ M.Sc, Dayana Salas-Leiva, ${ }^{2}$ Ph.D.
}

\begin{abstract}
${ }^{1}$ Universidad Católica del Norte, Facultad de Ciencias del Mar, Departamento de Acuicultura, Larrondo 1281, Coquimbo, Chile. 'Dalhousie University, Centre for Comparative Genomics \& Evolutionary Bioinformatics, Halifax, Nova Scotia, B3H 4R2, Canada. *Correspondencia: jsalasleiva@gmail.com
\end{abstract}

Received: March 2015; Accepted: May 2015.

\begin{abstract}
Objective. The effect of cryopreservation on the proximate composition of microalgae Chaetoceros calcitrans was evaluated. Materials and methods. C. calcitrans was cultured and cryopreserved using $5 \%(\mathrm{v} / \mathrm{v})$ dimethylsulfoxide as cryoprotectant. The freezing was controlled at a rate ${ }^{\circ} 3^{\circ} \mathrm{C} / \mathrm{min}$, up to $-60^{\circ} \mathrm{C}$ and then the microalgae were immersed in liquid nitrogen $\left(-196^{\circ} \mathrm{C}\right)$. After storage in liquid nitrogen, microalgae were rapidly thawed out and subcultured. The percentage of proteins, lipids and carbohydrates was analyzed using absorption spectrophotometry and the organic matter was studied by gravimetric analysis. Results. There was no significant variation between the proximate composition of $C$. calcitrans cryopreserved and the controls $(p>0.05)$. Conclusion. Our results show that, despite low cell recovery after the preservation of this organism at low temperatures, there is no apparent loss of nutritional characteristics caused by the storing process at low temperatures.
\end{abstract}

Key words: Diatom, freezing, nutrients, storage viability (Source: AGROVOG, DeCS).

\section{RESUMEN}

Objetivo. En este estudio se evaluó el efecto de la técnica de criopreservación sobre la composición proximal de la microalga Chaetoceros calcitrans. Materiales y métodos. $C$. calcitrans fue cultivada y criopreservada empleando dimetilsulfóxido al $5 \%(\mathrm{v} / \mathrm{v})$ como crioprotector. La congelación fue controlada a una tasa de $3^{\circ} \mathrm{C} / \mathrm{min}$, hasta llegar a $-60^{\circ} \mathrm{C}$ y luego las microalgas fueron sumergidas en nitrógeno líquido $\left(-196^{\circ} \mathrm{C}\right)$. Posteriormente, las microalgas fueron descongeladas de manera rápida y nuevamente cultivadas. Seguidamente se analizó la cantidad porcentual de proteínas, lípidos y carbohidratos, empleando espectrofotometría de absorción y la materia orgánica por gravimetría. Resultados. Los resultados indicaron que la composición proximal posterior a la criopreservación no evidencia diferencias significativas respecto a los controles no criopreservados $(p>0.05)$. Conclusiones. Los resultados indican que pese a la baja viabilidad post-criopreservación de $C$. calcitrans, no hay pérdida aparente de la composición nutricional debida al almacenamiento a bajas temperaturas.

Palabras clave: Almacenamiento, congelación, diatomea, nutrientes, viabilidad (Fuente: AGROVOG, DeCS). 


\section{INTRODUCTION}

Microalgae are a rich source of proteins, lipids and carbohydrates. They are used in aquaculture as food source in at least one stage of the life cycle of fish, mollusks and crustaceans. In hatcheries, sub-culture is generally used to maintain different strains of microalgae. This could potentially introduce biological contamination in the culture, subsequent loss of the strains, an increase of the farming costs, and at the same time, can affect the biochemical or genetic characteristics of the strains. Those problems can be tackled by maintaining collections of cryopreserved cultures, which aim to keep viable strains during long periods of time with minimal changes in their characteristics (1).

Microalgae cryopreservation is applied for various purposes. In cases where microalgae are used as nutritional sources, with low cell viability after cryopreservation as in the case of Chaetoceros calcitrans (viability $<40 \%$ ) (2), it is necessary to study whether the survivor cells have similar or different proximate composition to the one observed before freezing. SanchezSaavedra and Nuñez-Zarco (3) indicate that a low storage temperature of $4^{\circ} \mathrm{C}$ (during 1 to 6 weeks) influences cell density and proximal composition in cultures of the diatoms Navicula $s p, N$. incerta, N. thermalis and Nitzschia laevis. The purpose of this study was to analyze the proximate composition of the diatom $C$. calcitrans before and after one cycle of cryopreservation. C. calcitrans is an important source of omega $3(C \geq 20)$ and polyunsaturated fatty acids ( $n-3$ PUFA, mainly eicosapentaenoic acid: EPA, 20: $5 \mathrm{n}-3$ ). These nutrients make this microalga attractive for feeding filter-feeding mollusks, echinoderms, crustaceans and some zooplankton taxa (4).

\section{MATERIALS AND METHODS}

Cultivation and Cryopreservation. Batch cultures of $C$. calcitrans using micro-filtered sterile sea water were grown. Culture conditions, cryopreservation protocol and viability estimations are broadly described in Salas-Leiva and Dupré (2). A brief description of the cryopreservartion protocol is presented here: dimethylsulfoxide (Me2SO, 10\%) (Sigma, St. Louis, MO) was added to the cells at 4 and $25^{\circ} \mathrm{C}$ in complete darkness ( $1: 1$ proportion in $\mathrm{mL}$ ). Each suspension (microalgae-cryoprotectant) was introduced into $0.5 \mathrm{~mL}$ straws (IMV France) and incubated during 15 or 45 min [treatments 6: OC-0445 and 18: OC-2515 in Salas-Leiva and Dupré (2)]. Straws were subsequently frozen to $-60^{\circ} \mathrm{C}$ at a rate

\section{INTRODUCCIÓN}

Las microalgas son una fuente rica de proteínas, lípidos y carbohidratos. Estas son usadas en acuicultura como alimento en al menos una etapa del ciclo de vida de peces, moluscos y crustáceos. En granjas productoras, generalmente, el mantenimiento de las cepas de microalgas se lleva a cabo por subcultivo, lo cual puede traer consigo problemas como la contaminación de la cepas y la pérdida de las mismas, un aumento en los costos de producción y también puede incidir en el cambio de las características de las cepas por las cuales fueron seleccionadas como fuentes nutricionales. Las colecciones de cultivo criopreservadas representan la solución a estos problemas, ya que permiten mantener cultivos sin contaminación, viables a lo largo del tiempo y con cambios mínimos en sus características (1).

En microalgas la criopreservación ha tomado mucha fuerza por las ventajas anteriormente mencionadas. Sin embargo, cuando la viabilidad posterior a la criopreservación es baja, como lo es en el caso de Chaetoceros calcitrans (viabilidad $<40 \%$ ) (2), es necesario indagar si los microorganismos sobrevivientes presentan una composición proximal similar a la observada en la cepa antes de ser criopreservada, es decir, si la cepa conserva las características nutricionales iniciales. Resultados obtenidos por Sánchez-Saavedra y Nuñez-Zarco (3) indican que el almacenamiento a baja temperatura de refrigeración $\left(4^{\circ} \mathrm{C}\right)$ (durante 1 a 6 semanas) influye en la densidad celular y en la composición proximal de los cultivos de las diatomeas Navicula sp, $N$. incerta, $N$. thermalis y Nitzschia laevis. El propósito de este estudio fue analizar la composición proximal de la diatomea $C$. calcitrans antes y después de un ciclo de criopreservación. C. calcitrans es una fuente importante de ácidos grasos omega 3 de cadena larga $(C \geq 20)$ y ácidos grasos poliinsaturados $(n-3$ PUFA), principalmente ácido eicosapentaenoico (EPA, 20:5 n-3). Dichos nutrientes hacen que esta microalga sea utilizada en la alimentación de moluscos filtradores, crustáceos y también en zooplancton (4).

\section{MATERIALES Y MÉTODOS}

Cultivo y criopreservación. Se realizaron cultivos tipo batch de $C$. calcitrans empleando agua de mar envejecida microfiltrada y autoclavada. Las condiciones de cultivo, criopreservación y estimaciones de viabilidad se encuentran descritas en Salas-Leiva y Dupré (2). El protocolo de criopreservación empleó dimetilsulfoxido $\left(\mathrm{Me}_{2} \mathrm{SO}\right)$ (Sigma, St. Louis, MO) al 10\% (v/v), el cual fue adicionado en proporción $1: 1$ 
of $3^{\circ} \mathrm{C} / \mathrm{min}$ and then stored in liquid nitrogen $\left(-196^{\circ} \mathrm{C}\right)$. The viabilities of the treatments that had significant differences were $15.6 \pm 8.4 \%$ (OC$0445)$ and $31.7 \pm 7.7 \%$ (OC-2515). The recovered (thawed out treatments) and control cells (cells never cryopreserved from the same original strain used to cryopreserve) were inoculated into beakers of $250 \mathrm{~mL}$ and kept for 5 days. Then, an intermediate culture was grown in a volume of $1400 \mathrm{~mL}$ and five days later were transferred to bottles of $5 \mathrm{~L}$. For conditions and culture media review Salas-Leiva and Dupré (2).

Proximate composition. Thorough nutrient analysis methods are complex and costly to implement; for instance gas or liquid chromatography can be used to observe small variations in the levels of fatty acids and amino acid profiles. This research selected a basic and simple methodology, with good sensitivity and low cost that can potentially be used in small laboratories or in variable ground conditions in producing farms.

The analysis was done for the recovered cells and the control. After six days of culture (stationary phase), a sample of $2 \mathrm{~L}$ of each of the three cultures was removed and centrifuged at 6000 r.p.m. for $6 \mathrm{~min}$. The pellets were washed with isotonic ammonium formate (3.4\%) to remove salts, and dried at $70^{\circ} \mathrm{C}$ until a constant weight was obtained. The ash-free dry weight was obtained by subjecting the sample to $500^{\circ} \mathrm{C}$ for $6 \mathrm{~h}$. The percentage of proteins, lipids, carbohydrates, and organic matter of the three cultures was determined for $C$. calcitrans. Proximal analyses were performed using colorimetric techniques, with an absorption spectrophotometer Shimadsu (UV150-02). Proteins, lipids and carbohydrates were analyzed with techniques in references (5) to (7). Serum albumin, cholesterol and glycogen were used as standards (Sigma, St. Louis, MO). The organic matter in the samples was studied by gravimetric analyses according to Costard et al (8).

Statistical Analysis. The experimental design was a completely randomized block with one single factor and four levels. Three replicates were done and the result for each nutritional component was recorded as percentage of dry weight. For the analysis of variance, we first tested normality, homogeneity of variance and random data sequence with the Shapiro-Wilks, Barlett's and runs tests respectively, and Tukey's test for additivity. A one-way ANOVA for each nutrient was done separately. For all analyzes, we used SAS 9.3.1®. (microalga:crioprotector) para una concentración final de $5 \%(\mathrm{v} / \mathrm{v})$. El $\mathrm{Me}_{2} \mathrm{SO}$ fue añadido a la suspensión de microalgas a 4 y $25^{\circ} \mathrm{C}$ en oscuridad completa. Así, la concentración final del crioprotector fue de $5 \%(\mathrm{v} / \mathrm{v})$. Cada suspensión (microalgas-crioprotector) se introdujo en pajuelas de $0.5 \mathrm{~mL}$ (IMV, Francia) y se dejó incubar 15 o 45 min dependiendo del tratamiento [tratamiento 6: OC-0445 y 18: OC-2515, ver Salas-Leiva y Dupré (2)]. Posteriormente las pajuelas fueron congeladas hasta $-60^{\circ} \mathrm{C}$ con una tasa de $3^{\circ} \mathrm{C} / \mathrm{min}$ y luego sumergidas en nitrógeno líquido. Las viabilidades de los tratamientos mencionados fueron de $15.6 \pm 8.4 \%$ para OC-0445 y $31.7 \pm 7.7 \%$ para OC-2515. Los dos tratamientos descongelados y el cultivo control (nunca criopreservado) se inocularon en vasos de precipitado de $250 \mathrm{~mL}$ para iniciar un nuevo cultivo. Transcurridos 5 días en vasos de precipitado de $250 \mathrm{~mL}$, se llevaron a cultivo intermedio con volumen de $1400 \mathrm{~mL}$ y cinco días después fueron transferidos a botellas de $5 \mathrm{~L}$. Las condiciones y medios de cultivo fueron las mismas presentadas en Salas-Leiva y Dupré (2).

Análisis de composición proximal. Para el análisis minucioso de nutrientes existen métodos complejos con implementación de alto costo, como cromatografía de gases o líquida que permiten observar variaciones mínimas en los niveles de ácidos grasos y los perfiles aminoacídicos. Esta investigación seleccionó una metodología basica y sencilla, con buena sensitividad y bajo costo que potencialmente puede ser usada en pequeños laboratorios o en variadas condiciones de campo en granjas productoras.

El análisis fue llevado a cabo con las celulas de los tratamientos descongelados y el control. Luego de seis dias de cultivo, se extrajeron muestras de $2 \mathrm{~L}$ de cada uno de los tres cultivos y se centrifugaron a 6.000 r.p.m. por $6 \mathrm{~min}$. Los pellets fueron lavados con formiato de amonio isotónico (3.4\%) para eliminar las sales $y$, se secaron a $70^{\circ} \mathrm{C}$ hasta que se obtuvo un peso constante. El peso de la ceniza, se obtuvo sometiendo la muestra a $500^{\circ} \mathrm{C}$ por 6 horas en una mufla (Raypa). Se determinó el porcentaje de proteínas, lípidos, carbohidratos y materia orgánica a los tres cultivos de $C$. calcitrans. Los análisis proximales se realizaron mediante técnicas colorimétricas, con un espectrofotómetro de absorción Shimadsu (UV150-02). La estimación de proteínas, lípidos y los carbohidratos fue realizada con las técnicas expuestas en las referencias (5-7); los estándares fueron albúmina sérica, colesterol y glucógeno (Sigma, St. Louis, MO). La estimación de materia orgánica de las muestras se realizó 


\section{RESULTS}

The results indicated that the percentages of protein and lipid of the control were slightly greater than those of the thawed out treatments (Table 1). Carbohydrates in treatment OC0445 were slightly higher than those in the control and treatment OC-2515. In the case of organic matter, both treatments had slightly higher values than the control (Table 1). All treatments, fulfilled the assumptions of normality, homogeneity of variance, data independence and additivity $(p>0.05)$. ANOVA indicated that the proximate composition of microalgae subjected to cryopreservation (OC-0445 treatment and OC-2515) and the control was not significantly different (Table 2).

Table 1. Proximate composition of Chaetoceros calcitrans (percentaje of dry weight), control (not cryopreserved); O.M. (Organic matter); treatments: OC-0445 and OC-2515 (microalgae under cryopreservation). ( \pm ): Standard deviation.

\begin{tabular}{lcccc}
\hline Treatment & Protein & Lipids & Carbohydrates & O.M \\
\hline Control & $30.2 \pm 1.1$ & $15.5 \pm 1.5$ & $10.6 \pm 0.1$ & $40.8 \pm 1.1$ \\
OC-0445 & $28.3 \pm 1.7$ & $14.5 \pm 0.9$ & $11.3 \pm 0.3$ & $46.0 \pm 2.1$ \\
OC-2515 & $28.6 \pm 1.2$ & $14.3 \pm 1.6$ & $10.3 \pm 1.4$ & $44.6 \pm 4.4$ \\
\hline
\end{tabular}

Table 2. Factorial Analysis of Variance (ANOVA) randomized block for: Proteins, lipids, carbohydrates and organic matter. Degrees of freedom (df), sum of squares (SS), Square of the mean (SM), F (statistics) and $\mathrm{P}$ (significance level).

\begin{tabular}{lccccc}
\hline \multicolumn{1}{c}{ Source } & df & SS & SM & F-value & p-value \\
\hline Proteins & 2 & 6.409 & 3.204 & 1.19 & 0.393 \\
Replica & 2 & 0.329 & 0.164 & 0.06 & 0.942 \\
Error & 4 & 10.764 & & & \\
Total & 8 & 17.502 & 2.691 & & \\
Lipids & 2 & 2.406 & 1.203 & 0.71 & 0.544 \\
Replica & 2 & 5.323 & 2.662 & 1.57 & 0.313 \\
Error & 4 & 6.761 & & & \\
Total & 8 & 14.490 & 1.690 & & \\
Carbohydrates & 2 & 1.521 & 0.760 & 1.55 & 0.317 \\
Replica & 2 & 2.417 & 1.209 & 2.47 & 0.2 \\
Error & 4 & 1.958 & & & \\
Total & 8 & 5.897 & 0.489 & & \\
Organic mater & 2 & 50.32 & 25.16 & 2.13 & 0.234 \\
Replica & 2 & 7.12 & 3.56 & 0.30 & 0.755 \\
Error & 4 & 47.22 & & & \\
\hline Total & 8 & 104.66 & 11.810 & & \\
\hline
\end{tabular}

\section{DISCUSSION}

Under the conditions used in this experiment, viable cells of $C$. calcitrans seem to maintain their initial nutrient composition after one cycle of cryopreservation, despite a viability of mediante desecación, incineración y gravimetría según Costard et al (8).

Análisis estadístico. El diseño experimental fue de bloques completamente al azar con sólo un factor y cuatro niveles. Se efectuaron 3 réplicas y las variables de respuesta de cada componente nutricional fueron registradas en porcentajes de peso seco. Para el análisis de varianza se procedió a probar los supuestos de normalidad, homogeneidad de varianzas y sucesión aleatoria de datos con los test de Shapiro-Wilks, Bartlett y test de rachas respectivamente, además, se realizó el test de aditividad de Tukey específico para el modelo estadístico. Comprobados todos los supuestos se efectuó una ANOVA de una sola vía para cada uno de los nutrientes por separado. Todos los análisis se realizaron con el programa S.A.S 9.3.1 ${ }^{\circledR}$.

\section{RESULTADOS}

Los resultados indicaron que los porcentajes de proteínas y lípidos del control fueron levemente mayores a la de los tratamientos congelados (Tabla 1). Los carbohidratos del tratamiento OC-0445 fueron ligeramente superiores a los del control y del tratamiento OC-2515, mientras que la materia orgánica de los dos tratamientos fue superior a la del control (Tabla 1). Todos los tratamientos evaluados cumplieron los supuestos de normalidad, homogeneidad de varianzas, independencia de datos y aditividad $(p>0.05)$. El ANOVA indicó que la composición proximal de las microalgas sometidas a criopreservación (tratamiento OC-0445 y OC-2515) y la del control, no fueron diferentes (Tabla 2).

\section{DISCUSIóN}

Bajo las condiciones utilizadas en este experimento, las células viables de $C$. calcitrans parecen mantener sus características nutricionales iniciales, después de un ciclo de la criopreservación, pese a que el número de células viables estuvo únicamente entre 15 y $35 \%$. Algo similar fue reportado por Nakanishi et al (9) en cuatro tipos de microalgas, en los que el contenido de clorofila no cambió significativamente después de ser criopreservadas durante 15 años. En la actualidad existen pocos reportes sobre el estudio de la composición proximal de las microalgas después de ser criopreservadas. Dentro de estos reportes, se encuentra el de Esquivel et al (10) en Chaetoceros sp. en el cual los porcentajes de proteína, carbohidratos y lípidos de las microalgas criopreservadas, presentan una reducción de los componentes nutricionales con respecto a cultivos control no criopreservados. La reducción de algunos componentes en las muestras congeladas es el resultado de la ruptura celular que ocurre a bajas 
approximately 15 to $35 \%$. Something similar was reported by Nakanishi et al (9) in four types of microalgae, in those cells chlorophyll content did not show any significant change after being cryopreserved for 15 years. Among the few reports on the study of the proximate composition of microalgae after being cryopreserved, Esquivel et al (10) in Chaetoceros sp. found reduced percentages of protein, carbohydrate and lipids in cryopreserved microalgae respect to controls. The reduction in some components in frozen samples can be attributed to "cell leakage" which occurs at low temperatures (membrane damage causing loss of cell content).

Nuñes-Zarco y Sánchez-Saavedra (11) mentioned that refrigeration of benthic diatoms Navicula incerta and Amphiprora paludosa at $4^{\circ} \mathrm{C}$ causes small changes in the proximate composition (mainly lipids and organic matter). Subsequently Sanchez-Saavedra and Nuñez-Zarco (3) noted that storage at $4^{\circ} \mathrm{C}$ in darkness, causes an increase in protein content in Navicula $s p, N$. incerta and Nitzschia laevis, but an increase in the lipid content is only observed in $N$. incerta under those conditions. According to these researchers this change in the lipid content is consistent with that shown by plant cells after cooling at $5^{\circ} \mathrm{C}$, where the lipid content typically increases at the cell membrane to prevent formation of intracellular ice. Proximal changes in composition after storage at low temperatures are a type of species-specific response. The above mentioned results are not fully comparable to our research because they applied different preservation procedures. Nonetheless, we can suggest that the microalgae in our study retained the ability to grow and synthesize the basic components of biomass in similar proportions of the original strain. Here we have to highlight that most of the chemical and metabolic reactions are reduced exponentially at low temperatures, and differences in cells stored at $-20^{\circ} \mathrm{C}$ respect to those stored at $-100^{\circ} \mathrm{C}$ are expected (i.e. the lower the storage temperature, the smaller the change occurring in the cells). This means that the use of temperatures below the eutectic point of the mixture (cells-cryoprotectant solution) prevents damage of the cell for long periods of storage (12).

According to Brown et al (13), diatoms generally present protein composition ranging from $30 \pm 10 \%$, lipids between $14 \pm 5 \%$ and $7 \pm 3 \%$ carbohydrates. Our data fall within those ranges. The nutritional contents observed in our investigation are close to the ones reported for C. calcitrans, C. muelleri, C. gracilis and Chaetoceros sp. (14), and the slight observed temperaturas (daños a las membranas que causan pérdida de contenido celular).

Nuñez-Zarco y Sánchez-Saavedra (11) mencionan que la conservación de las diatomeas bentónicas Amphiprora paludosa y Navicula incerta a $4^{\circ} \mathrm{C}$, provoca pequeñas modificaciones en la composición bioquímica (principalmente lípidos y materia orgánica) con respecto a los controles. Posteriormente Sánchez-Saavedra y Núñez-Zarco (3) observaron que el almacenamiento a $4^{\circ} \mathrm{C}$ en oscuridad, provoca un aumento en el contenido de proteína en las diatomeas Navicula sp, $N$. incerta y Nitzschia laevis y un aumento en el contenido de lípidos únicamente en $N$. incerta (bajo esas condiciones). De acuerdo a estos investigadores este cambio en el porcentaje de lípidos es consistente con los datos sobre las células vegetales después de refrigeración a $5^{\circ} \mathrm{C}$, donde el contenido de lípidos típicamente aumenta en la membrana celular para prevenir la formación de hielo intracelular. Los cambios en composición proximal después del almacenamiento a bajas temperaturas son un tipo de respuesta especie-específica.

Los resultados obtenidos en el presente estudio, no son completamente comparables con los arriba mencionados puesto que fueron obtenidos mediante técnicas de conservación distintas. No obstante, si se puede mencionar que las microalgas viables luego de criopreservación a $-196^{\circ} \mathrm{C}$ mantuvieron la capacidad de sintetizar los componentes básicos de su biomasa en proporciones similares a las de la cepa original. Cabe anotar que la mayoría de las reacciones químicas y metabólicas se reducen exponencialmente a temperaturas bajas y se pueden esperar diferencias en las células almacenadas a $-20^{\circ} \mathrm{C}$ con respecto a las almacenadas a $-100^{\circ} \mathrm{C}$ (p.e. cuánto más baja es la temperatura de almacenamiento, menor es el cambio que ocurre en las células). Esto significa que el uso de temperaturas por debajo de punto eutéctico de la mezcla (células-solución crioprotectora), previene el deterioro de la célula durante largos períodos de almacenamiento (12).

De acuerdo a Brown et al (13), las diatomeas en general presentan una composición en proteínas que varían entre $30 \pm 10 \%$, lípidos entre $14 \pm 5 \%$ y carbohidratos $7 \pm 3 \%$, rangos entre los que se encuentran los datos de composición bioquímica obtenidos en este estudio. Por otra parte los contenidos nutricionales (proteínas, lípidos y carbohidratos) observados en esta investigación presentan valores cercanos a los reportados en $C$. calcitrans, C. muelleri, $C$. gracilis y Chaetoceros sp. (14). Las diferencias observadas en composición bioquímica entre los reportes citados con respecto a los de la presente 
differences can be due to several factors (i.e. photoperiod, culture media, harvesting stage, temperature, salinity, strain specificity) that affect the proximate composition (14).

In cases where cryopreservation is carried out with strains that have been previously cryopreserved (i.e. sequential cryopreservation), the storage technique may induce directional selection favoring those cells that are more adapted to counteract the effect of low temperatures (i.e. cells with a highly flexible cell wall, natural production of cryoprotectants, gene expression and protein accumulation associated with responses to low temperature (AFPs), or DNA methylation responses to protect against low temperatures)(15). This could be detected by the use of molecular tools such rtPCR analyzing transcription factors and/or molecular analysis of HSPs (heat shock proteins).

Finally, our research supports positively the idea that cryopreservation is an effective technique of preservation of microalgae while their nutritional characteristics is maintained during long periods of time.

\section{Acknowledgements.}

The authors thank Mr. Raúl Vera for his support in the laboratory of Biochemistry at the Universidad Cátolica del Norte (Chile). investigación pueden atribuirse a diversos factores del cultivo de las microalgas como: fotoperíodo, medio de cultivo, etapa de cosecha, temperatura, salinidad, especificidad de la cepa, las cuales influyen en la composición bioquímica (14).

En casos donde la criopreservación es llevada a cabo secuencialmente, es posible que ésta produzca algún tipo de selección direccional hacia células que son más aptas para contrarrestar el efecto de las bajas temperaturas [p.e. pared celular más flexible, producción de precursores de crioprotectores naturales, expresión de genes y acumulación de proteínas asociadas a respuestas a baja temperatura (AFPs) y respuestas de metilación de ADN para protegerse del frío (15). Esto podría detectarse mediante el uso de herramientas moleculares como RT-PCR, analizando factores de transcripción y/o análisis molecular de proteínas HSP (heat shock proteins).

Finalmente, esta investigación apoya positivamente la idea de que la criopreservación es un proceso efectivo para la preservación de microalgas debido a que mantiene sus características nutricionales.

\section{Agradecimientos.}

Los autores agradecen al Señor Raúl Vera por el apoyo en el laboratorio de Bioquímica de la Universidad Católica del Norte (Chile).

\section{REFERENCES}

1. Bui T, Ross I, Jakob G, Hankamer B. Impact of procedural steps and cryopreservation agents in the cryopreservation of Chlorophyte microalgae. PloS one 2013; 8(11):e78668.

2. Salas-Leiva J, Dupré E. Cryopreservation of the microalgae Chaetoceros calcitrans (Paulsen): analysis of the effect of DMSO temperature and light regime during different equilibrium periods. Lat Am J Aquat Res 2011; 39(2):271-279.

3. Sánchez-Saavedra M, Núñez-Zarco E. Photosynthetic and Biochemical Effects of Cold Storage on Marine Benthic Diatoms of the Mexican Pacific Coast. J World Aquacult Soc 2012; 43(2):249-258.

4. Miller M, Quek K, Staehler K, Nalder T, Packer $M$. Changes in oil content, lipid class and fatty acid composition of the microalga Chaetoceros calcitrans over different phases of batch culture. Aquac Res 2012; 45(10):1634-1647.
5. Anning $T$, MacIntyre $H$, Pratt $S$, Sammes P, Gibb S, Geider R. Photoacclimation in the marine diatom Skeletonema costatum. Limnol Oceanogr 2000; 45(8): 1807-1817.

6. Thiyagarajan V, Harder T, Qiu J, Qian P. Energy content at metamorphosis and growth rate of the early juvenile barnacle Balanus amphitrite. Mar Biol 2003; 143(3): 543-554.

7. Illman A, Scragg A, Shales S. Increase in Chlorella strains calorific values when grown in low nitrogen medium. Enzyme Microb Tech 2000; 27(8):631-635.

8. Costard G, Machado R, Barbarino E, Martino $\mathrm{R}$, Lourenço $\mathrm{S}$. Chemical composition of five marine microalgae that occur on the Brazilian coast. Int J Fish Aquaculture 2012; 4(9):191-201. 
9. Nakanishi K, Deuchi K, Kuwano K. Cryopreservation of four valuable strains of microalgae, including viability and characteristics during 15 years of cryostorage. J Appl Phycol 2012; 24(6):1381-1385.

10. Esquivel B, Lobina D, Sandoval F. The biochemical composition of two diatoms after different preservation techniques. Comp Biochem Physiol 1993; 105B (2):369373.

11. Núñez-Zarco E, Sánchez-Saavedra M. Cold Storage of Six Marine Benthic Diatoms Native to the Mexico Pacific Coast. J World Aquacult Soc $2011 ; 42(4): 530-538$.

12. Taylor R, Fletcher L. Cryopreservation of eukaryotic algae: a review of methodologies. J Appl Phycol 1999; 10:481-501.
13. Brown M, Jeffrey S, Volkman J, Dunstan G. Nutritional properties of microalgae for mariculture. Aquaculture 1997; 151:315331.

14. Banerjee S, Hew W, Khatoon $\mathrm{H}$, Shariff $M$, Yusoff $F$. Growth and proximate composition of tropical marine Chaetoceros calcitrans and Nannochloropsis oculata cultured outdoors and under laboratory conditions. Afr J Biotechnol 2011; 10(8):1375-1383.

15. Johnston J, Benson E, Harding K. Cryopreservation induces temporal DNA methylation epigenetic changes and differential transcriptional activity in ribes germplasm. Plant Physiol Bioch 2009; 47:123-131. 